\title{
The Effects of 2-tier Store Brands' Perceived Quality, Perceived Value, Brand Knowledge, and Attitude on Store Loyalty
}

\author{
(C) Higher Education Press and Springer-Verlag 2010
}

\begin{abstract}
This paper divides store brands into generic ones versus individual ones. Accordingly, two types of store brand loyalty are discussed, namely general versus individual brand loyalty. It also analyzes perceptions of 2-tier store brands in terms of perceived quality and value, and explores the respective effects of consumer knowledge and brand attitude on store loyalty. Results show that both low-priced and medium-priced store brands are able to build individual store brand loyalty and store loyalty among customers. Managerial implications are also provided.
\end{abstract}

Keywords 2-tier, store brand, store loyalty, individual store brand loyalty, perceived quality

\section{Introduction}

The implementation of marketing strategies has become extremely important due to increasingly fierce competition. It has been found that performance of a retail store is determined by its attractiveness, market condition (i.e. site selection and trading areas), customers' demographic characteristics, and competition situation

Translated from Yingxiao Kexue Xuebao 营销科学学报 (Journal of Marketing Science), 2008, 4(1): 69-85

Defeng Yang $(\varangle)$

School of Management, Jinan University, Guangzhou 510632, China

E-mail: yangdefeng@163.com

Xinxin Wang

School of International Business Administration, Shanghai University of Finance and Economics, Shanghai 200433, China

E-mail:wxx777@sina.com 
(Reinartz and Kumar, 1999). Retailers need to provide customers with good reasons for shopping in their stores rather than in their competitors'. Moreover, retailers also need to create differentiation and store loyalty (Bridson and Evans, 2004). Once customers' store loyalty is established, retailers will gain competitive advantages (Sirgy and Samli, 1985). Numerous empirical studies have demonstrated that customers' loyalty has a positive correlation with retailer profit (e.g., Rafiq and Fulford, 2005).

In terms of consumer behavior theory, store selection process is affected to a high degree by store attributes such as product-related factors (Pan and Zinkhan, 2006). For this reason, customers' store selection and store loyalty can be influenced by the products sold in a store. In order to strengthen such attractiveness, one of the strategies often used by retailers is to introduce store brands (Harcar et al., 2006). Store brands (or private labels) are product brands owned by a retailer (Hansen et al., 2006). A considerable amount of academic research has shown that store brands, controlled and exclusively distributed by retailers, help improve gross margin, increase retailers' negotiation power with manufacturer brands (i.e. product brands owned by manufacturer firms), attract more customers, and build differentiation because of their exclusive distribution (Miquel et al., 2002), hence develop store loyalty (Corstjens and Lal, 2000; Wang and Yang, 2007).

As retailers pay more attention to store brands' quality, and give store brands more shelf-space, store brands have gained a certain advantage over manufacturer brands (Fu, 2001; Li and Chen, 2006). For example, considering the 250 supermarket product categories in the United States, store brands have the highest market share among 77 product categories, and rank in second or third place in another 100 product categories (Quelch and Harding, 1996). In UK, as a leader in developing store brands in Europe, the market share of some UK retailers' store brands is as high as $40 \%-50 \%$ (Johanson and Burt, 2004).

Store brands are often characterized by "higher quality, lower price", the referred brand positioning is the leading or the-lowest-price manufacturer brands. However, if competitive retailers all keep their store brands positioning in the "higher quality, lower price" category, can store differentiation and store loyalty be eventually created? Agreement has not been reached among scholars in this respect. For example, Rao (1969) and Richardson (1997) proposed that because there are no differences in store brands' perceived quality among all store brands offered by all retailers, consumers will not be particularly loyal to one certain store brand. However, some other scholars have opposite opinions. For instance, Corstjens and Lal's (2000) game model argues that high-quality store brands can build store loyalty.

In order to improve store brand purchasing, some scholars suggested retailers 
should increase consumers' store brand knowledge (Mieres et al., 2006) and enhance consumers' store brand attitude (Burton et al., 1998), apart from laying great emphasis on store brands' quality and value (Richardson et al., 1994). However, there is a lack of corresponding empirical studies on whether these marketing strategies have effect on store brand loyalty and store loyalty. Based on the above research controversies and gaps, this article aims to address the following questions: First, is store brand loyalty influenced by store brands' perceived quality? Second, is money-saving value or quality value more useful to the creation of store brand loyalty? Third, consumers' increase of store brand knowledge and attitude is useful to the purchase tendency of store brands, but is it still useful to the creation of store loyalty? And is there any spillover effect? Fourth, would different tiers of store brands lead to different effect on store loyalty?

\section{Literature Review}

\subsection{Multi-tier Retailer Store Brands}

Different store brands have been introduced by retailers in order to satisfy consumers' demands in different market segments. On the basis of positioning differentiation, store brands are divided into 2-tier (Steiner, 2004) or 3-tier (Lamey et al., 2007) store brands. For example, a 3-tier store brand strategy is generally implemented by retailers in the UK. Based on Lamey et al. (2007), Steiner (2004) and other related literature, store brands are divided into the low-priced tier, mid-priced tier, and high-premium tier in this article, and only low-priced tier and mid-priced tier are examined, as shown in Fig. 1.

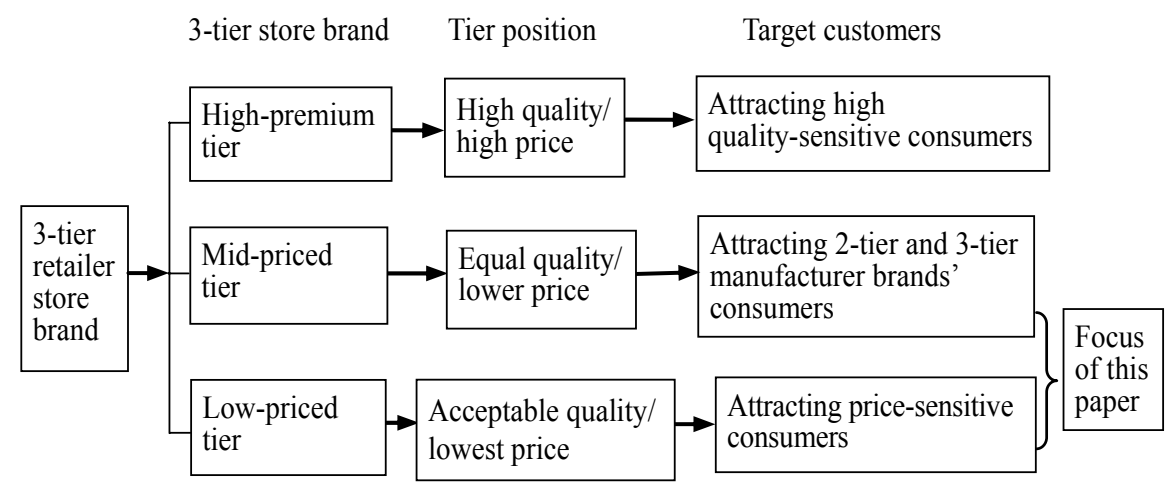

Fig. 1 The Position and Target Customers of the 3-tier Retailer Store Brand Source: Lamey et al. (2007), Steiner (2004) and other related studies. 
Low-priced tier positions on "acceptable quality, the lowest price". This kind of store brands offer products with lower, but acceptable quality, and with the lowest price in all product categories to attract price-sensitive customers. The quality of high-premium tier, aiming at attracting price-insensitive customers prefers high-quality products, positioning on "high quality, high price". The quality of store brand products pursuing high-premium strategy may be even higher than the leading brands while their price is similar to the leading brands. The "organic/green" store brands launched by many European retailers belong to this high-premium tier. Mid-priced tier positions on "equal quality but lower price" with leading brands. Although this tier's products own the equal quality tier along with the leading brands, their price is often 20\%-30\% lower than the leading brands, which accordingly, attract customers from the second and third tier of manufacturer brands. That's because the price decrease of high-quality brands not only provides an opportunity for consumers to switch from low-quality brands to high-quality brands, but also provides them with higher utility. Even though the price decrease of low-quality brands also has some attraction, it cannot bring the desirable quality effect. For this reason, there is an asymmetrical phenomenon between low-quality brands and high-quality brands (Sivakumar and Rai, 1997). The customers of the second and third tier manufacturer brands switching upwards to store brands results in the loss of these two tiers' market shares.

\subsection{Factors Influencing Store Brand Loyalty}

Consumers' preference for one certain brand in terms of purchase behavior and attitude, forms brand loyalty. Brand loyalty can be divided into behavioral loyalty, emotional loyalty, cognitive loyalty, and intentional loyalty (Wang et al., 2003). Scholars often conduct research on brand loyalty from the perspective of consumers, and key emphasis is put on the dimensions and influence factors of customer loyalty. Concerning the factors influencing customer loyalty, Yang and Peterson's (2004) model reveals that perceived value not only has a direct positive effect, but also has an indirect positive effect through customer satisfaction. Besides, switching cost plays a moderating role in the effect of customer value and customer satisfaction on customer loyalty. Furthermore, Bai and Liu (2002) proposed that the direct driving factors of customer loyalty include service quality, customer satisfaction, and switch cost, while indirect influence factors include technological changes, social criterion, and situational factors. What's more, the customer loyalty driven model developed by $\mathrm{Lu}$ (2005) suggests that customer loyalty can be divided into attitude loyalty, service loyalty, and behavioral loyalty, all of which are positively affected by customers' 
satisfaction. In addition, Huang et al. (2004) argued that the most important way to improve customer loyalty is to enhance customer satisfaction. In order to improve customer satisfaction, the vital method is to improve customers' product and service quality cognition. According to the research above, it is concluded that perceived quality and perceived value are two important factors which are very relevant to customer loyalty. This article will also focus on the effect of these two variables on store brand loyalty and store loyalty.

\subsubsection{Store Brands' Perceived Quality and Perceived Value}

Perceived quality is the commonly accepted definition of "perceived quality", though without controversy among different scholars, is that "perceived quality is customers' subjective judgment on objective quality". Thus, Kirmani and Baumgarther (2000) hold that quality evaluation, similar to attitude evaluation, is the evaluation of brand benefits provided to consumers, which will easily lead to deviation from perceived quality to objective quality. For example, although the quality of store brands can match with national brands in terms of product ingredients, considerable research has shown that from the perspective of consumers' perception, store brands still have the image of poor-quality, compared to national brands (According to market occupation area, manufacturer brands are usually classified into national brands and regional brands) (Richardson et al., 1994). Chinese scholars have shown that customers have low evaluation on the quality of Chinese local retailers' store brands (Jiang and Guo, 2003; Xu and Jiang, 2007; Wang, 2006).

Perceived value is a multi-faceted construct (for a review, see Smiths et al., 2007). For example, Darasurman and Grewal (2000) classified perceived value into acquisition value, transaction value, used value and residual value. Smith and Colgate (2007) divided perceived value into functional/instrumental value, experiential/hedonic value, symbolic/expressive value and cost/sacrifice value. In the positioning of the three tiers of store brands, retailers always focus on quality and price. Therefore, the study will follow Richardson et al. (1994), and only adopt money-saving value and quality value in the study of store brand's perceived value.

\subsubsection{Consumers' Store Brand Knowledge and Attitude}

In terms of research on customers' characteristics and purchase behavior, scholars have found that consumers' store brand knowledge has a positive correlation with their purchase intention. For example, Mieres et al. (2006) demonstrated that consumers' familiarity with store brands can help improve their perceived quality. Sprotta and Shimp (2004) proved that consumers' trial 
use of products of store brands will improve their perceived quality. Dick et al. (1995) found that the reason why customers have a weak store brand's purchase tendency is that they are unfamiliar with store brands and unaware of their characteristics of "high quality, low price". Richardson et al. (1996) also pointed out that consumers' familiarity with store brands will affect their purchase tendency.

Consumers' store brand attitude has also a positive correlation with their purchase intention (Burton et al., 1998). Burton et al. (1998) found that consumers' price and value consciousness is positively related to their store brand attitude, while consumers' price-quality schema has a negative correlation. Consumers, who are less loyal to brands (also called less brand inertia), are more likely to switch to other brands, so brand loyalty is positively correlated with store brand attitude. Consumers' transaction tendency, including generic transaction tendency, price and non-price transaction tendency, has a positive correlation with store brand attitude. Scholars have also acknowledged that store brand knowledge and attitude are both positively correlated with the purchase of store brand; however, they have not investigated the effect of these two variables on store brand loyalty and store loyalty. Accordingly, this article is dedicated to filling the gap.

\subsection{Store Selection and Store Loyalty}

Consumers' store selection behavior has been explored by previous research from various perspectives. According to the store site selection model (Bell et al., 1998), scholars pointed out that store selection behavior is mainly determined by store location and distance. And some researchers even argued that store location explains the $70 \%$ variance of consumers' store loyalty. Yet, the retail price model developed by Bell et al. (1998) states that store selection behavior is mainly determined by promotion and price discounts. The consumer behavior theory asserts that store selection behavior is affected by a number of store attributes (for more details, please refer to Pan and Zinkhan, 2006; Paulins and Geistfeld, 2003). In Pan and Zinkhan's (2006) meta-analysis of store selective behavior, store selection behavior is classified into three categories: the first is product-related, such as product quality, price, product selectivity; the second kind is market-related, such as convenience, service quality, store image, store atmosphere, etc., and the third is personnel-related, such as customer demographic variable, etc. With respect to the degree of effect, it is concluded that the factors influencing store selection are, in descending order of significance, product selectivity, service quality, product quality, store atmosphere, store location, price, checkout speed, business hours, service people's kindness, and parking convenience. Further, the factors, which have an 
impact on the patronage frequency, are consumers' store attitude, store image, and consumers' gender. Obviously, products sold by the stores are important variables which have an impact on consumers' store selection. This paper will mainly explore the effect of store brand products on store loyalty.

Scholars believe that store loyalty is not just a kind of repeated patronage behavior, the same as customer loyalty. For example, Bloemer and Ruyter (1998) stated that store loyalty and repeated patronage behavior are two different concepts. Actually, repeated patronage behavior means that customers shop in a store repeatedly, but store loyalty means more. Reynolds and Arnold (2002) agreed that store loyalty is "willing and inclined to patronize a store continuously". In addition, Bloemer and Ruyter (1998) argued that store loyalty is a function of consumers' psychological process gained from brand commitment and the behavior of shopping in a store selectively and continuously. They suggested that the core of store loyalty is store commitment, and the behavior of shopping in a store frequently but without store commitment is a spurious loyalty. This behavior may come from customers' inertia rather than real loyalty. Furthermore, store commitment indicates a close connection between store selective behavior and consumers. If consumers are not attracted by store attributes and there are no store commitments, they will be easily attracted away by competitors. Accordingly, it can be seen that store loyalty includes consumers' behavior loyalty and attitude loyalty, as adopted in this paper.

In terms of the specific factors influencing store loyalty, Bloemer and Ruyter (1998) found that both of store satisfaction and store image have significant impact on store loyalty. Furthermore, Chen and Quester's (2006) model shows that customers' satisfaction and employee performance both play important roles in store loyalty. What's more, Miranda et al. (2005) proposed that the factors affecting store loyalty include goods' cumulative score rebates plan, store distance, store-cooked meat, purchase amount, shelf familiarity, marketing support, etc. Koo (2003) also suggested that store loyalty is determined by store location, product quality, and after-sales service. Obviously, product factors are important factors of influencing customers' store loyalty.

However, products of store brands are a special kind of products. Manufacturer brands can be purchased in other stores, while store brands can only be bought in the related stores. Accordingly, if customers are loyal to store brands, they may also become loyal customers of this store. For example, Cunningham (1961) studied 16 product categories, and found that store brand loyalty is positively correlated with store loyalty in 13 product categories. Corstjens and Lal's (2002) finding revealed that even if store brands do not have cost advantage relative to manufacturer brands, under the condition that store brands are with high quality and customers are brand-inertia, they could build 
store loyalty by increasing customers' switching cost. Yet, some scholars consider that store loyalty cannot be developed by store brands (Rao, 1969; Richardson, 1997); other studies hold consumers heavily buy store brands is not beneficial to retailers (Ailawadi et al., 2008). However, in previous literature, when the effect of store brands on store loyalty was explored, little attention has been paid to different positioning store brands, and there has been a lack of research about the Chinese market. Based on the above reasons, this article will address the effect of low-priced tier and mid-priced tier store brands on store loyalty.

\section{Research Framework and Hypotheses}

Compared with manufacturing brands, all retailers' store brands have some features in common. Store brands belong to retailers, and production of these products mainly relies on manufacturing firms. In addition, retailers do not have core or flagship products. In order to satisfy needs of different consumers, a number of store brands have been introduced with different brand names. Compared with national brands, the coverage of store brands is often much bigger, and sometimes it is so wide that the whole store's products may be given the same store brand name, which is an extreme case in brand extension. Generally, store brands' emphasis is put on quality and price, rather than emotional value or symbolic value. Store brands have also some special characteristics. Due to coverage of different logos and product categories, there is some difference between different retailers' store brands. Even different store brands held by the same retailer may differ due to different positioning and coverage of different product categories. For example, in the Chinese market, the store brands of Carrefour Supermarket include grocery brand "Carrefour", clothing brand "French Touch", home appliances brand "Firstline" and fresh brand "Carrefour Quality Line".

Consumers' purchase choice of store brands can be divided into two levels. First, consumers' willingness to buy "all retailers' store brands" instead of manufacturing brands; in other words, no matter which retailers the store brands belong to, consumers are willing to buy them rather than manufacturing brands (Rao, 1969; Richardson, 1997). Second, compared with other store brands, consumers have higher purchase willingness on "one retailer's certain store brand", that is, they only present the higher brand loyalty for just one store brand (Corstjens and Lal, 2000). The above two levels have different meanings. "All retailers' store brands" are related to manufacturing brands and are a kind of brands owned by retailers, and it is a brand category concept. Yet, "one retailer's certain store brand" is a certain brand owned by one retailer, and it is an 
individual brand. However, few scholars have attempted to distinguish the two concepts. Instead, "store brands" is used to refer to either "all the store brands" or "one certain store brand" (Corstjens and Lal, 2000). As a consequence, it is very inconvenient when we explore the relationship between store brands and store loyalty. Obviously, it is very necessary to distinguish these two levels of store brands.

Thus, we define the above two concepts as generic and individual store brand, respectively. We define "all retailers' store brands", corresponding to manufacturing brands, as generic store brand, while we define "one retailer's certain store brand" as individual store brand. The relationship between the two concepts is similar to that of between "group and individual", as shown in Table 1. The logic underlying our concept framework is that store brands possess group and individual characteristics and thus can be divided into subgroups (as we do with manufacturing brands). In comparison with manufacturing brands, store brands share some common characteristics of their own as a group, but when we study store brands separately; we will find that all of them have their own characteristics. Thus, we propose two concepts as generic and individual store brand. Generic store brand is a concept corresponding with manufacturing brands, and means "all the retailers' store brands". Obviously, according to the dimension of brand owners, brands can be divided into two categories: manufacturing brands, including all the brands owned by manufacturers, such as Haier, Lenovo and generic store brands, including the brands owned by all retailers, such as Lianhua, Carrefour, as shown in Table 1. Individual store brand is the name of one single store brand, and is the definition in the scope of store brands. For example, Lianhua, Lianhua-jiahui, Carrefour and French Touch, etc., are all individual store brands.

Table 1 Examples of Different Generic and Individual Store Brands

\begin{tabular}{ll}
\hline \multicolumn{1}{c}{ Brands } & \\
\hline Generic store brands & Manufacturer brands \\
\hline Individual store brand & \\
Lianhua & Haier \\
Lianhua-jiahui & Lenovo \\
Carrefour & Tsingtao \\
French Touch & Nestle \\
Firstline & Rejoice \\
$\ldots$ & $\ldots$ \\
\hline
\end{tabular}

Source: The official websites of the above brands.

Accordingly, we classify store brand loyalty into generic and individual store brand loyalty. Generic store brand loyalty means that consumers show their loyalty to generic store brand rather than manufacturing brand loyalty, that is, no 
matter which retail store consumers shop in, consumers prefer to purchase store brands instead of manufacturing brands. Individual store brand loyalty means that consumers are loyal to one certain store brand rather than other individual store brands. In other words, consumers show higher loyalty to one certain store brand. Contrary to previous research, we can examine the relationship between store brand loyalty and store loyalty easier, and pertinently study the effect of store brand loyalty on store loyalty.

\subsection{Store Brands' Perceived Quality and Store Brand Loyalty}

Highly functional, store brands can not provide consumers with higher emotional value or symbolic value than that of manufacturer brand. As a result, most store brands regard consumers' perceived value as a priority. As value is the ratio of quality and price, there must be a positive relationship between perceived quality and value of store brand products. In addition, the important factor influencing manufacturer brand loyalty is product quality (Huang et al., 2004), and the key factor influencing consumers' purchase of store brands is perceived quality (Sayman et al., 2002).Therefore, we can assume that whoever do not want to buy store brands, either think that store brands are poor quality, low nutritional value, or contain unreliable ingredients (Dick et al., 1995). If retailers put emphasis store brands' selling point on quality, rather than price, this tactics will improve store brands' perceived quality and increase consumers' store brand loyalty (Richardson et al., 1994). Store brands' perceived quality is one of the important factors influencing consumers' first purchase, repeat purchase and their attitude preference (Richardson et al., 1994), and is also one of the key factors determining store brand market share (Dhar and Hoch, 1997). Thus, this study proposes the following two hypotheses:

H1a Store brands' perceived quality has a positive effect on perceived value.

H1b Store brands' perceived quality has a positive effect on individual store brand loyalty.

The quality of the products sold in stores plays an important role in consumers' store selection behavior, and consumers' perception of product quality is associated with the tendency to store patronization. Numerous studies have shown that product quality has a positive correlation with store patronizing behavior (Koo, 2003; Pan and Zinkhan, 2006). Till now, although the image of store brands' quality still lags far behind that of national brands quality, the gap has been narrowed significantly. The quality of the-lowest-priced tier store brands is lower, but it can be accepted. For this reason, these store brands attract price-sensitive consumers. Mid-priced tier store brands have equal quality with leading manufacturer brands; and the quality of high-premium tier store brands 
can be comparable to the leading brands, which therefore attract consumers most sensitive to quality. Therefore, this study assumes that:

H1c Store brands' perceived quality is positively related to store loyalty.

\subsection{Store Brands' Perceived Value and Store Brand Loyalty}

Store brands position on perceived value, which is the ratio of quality and price, and emphasize different value, money-saving value or quality value in different tiers (Richardson et al., 1994). For example, in mid-priced tier, Ailawadi et al. (2001) found that store brands frequently imitate the leading brands in the categories, and then stress "equal quality, lower prices". Perceived value has a direct and indirect positive effect on consumers' brand loyalty (Yang and Peterson, 2004). Therefore, it is expected that store brands' perceived value also has an important impact on store brand purchase and loyalty. Therefore we develop Hypothesis H2a as follows:

H2a Store brands' perceived value is positively related to individual store brand loyalty.

Corstjens and Lal (2000) suggested that consumers have higher inertia with high-quality store brands (consumers' reluctance to switch away from the previous brand) and lower inertia with poor-quality and lower-price store brands. Therefore, store brands' quality value has more important effect on consumers' store brand loyalty than money-saving value. Richardson et al. (1994) also found that the purchasers of store brands prefer to care about store brands' "quality value" rather than their "money-saving value", and they pay more attention to quality benefits gained from store brands. In five product categories, they found that the price of store brands is $21 \%$ lower than that of national brands, but from the consumers' perception perspective, the "money-saving value" of store brands is only seven percent higher than that of national brands.

H2b In terms of store brands' money-saving value and quality value, consumers pay more attention to their quality value.

\subsection{Consumers' Store Brand Knowledge, Attitude and Loyalty}

Consumers' familiarity with a particular brand, as consumers' knowledge, may be used to the purchase of other store brands, and hence developed into store brand knowledge. This store brand knowledge plays an important role in consumers purchase. Competitive retailers are pursuing a similar position in each store brand tier. After purchasing several retailers' store brands, consumers are more likely to buy store brands rather than manufacturer brands, on condition 
that they have realized that store brands are able to provide higher perceived value than manufacturer brands. For example, Rao (1969) found that store brands' success of a retailer is relevant to that of other retailers. In other words, there is a spillover effect of consumers' store brands purchase behavior. The reason behind this is that consumers' purchasing experiences increase their tendency to buy store brands in any stores. In addition, studies have shown that consumers' familiarity with store brands can enhance their perceived quality, and when consumers possess more store brand knowledge, their tendency to buy store brands will increase (Mieres et al., 2006). Besides, Lamey et al. (2007) proposed that in an economic slump, people tend to buy store brands, but when economy starts to recover, some of these consumers will go back to purchase manufacturer brands, while others will continue to buy store brands. With the increase of store brand knowledge, consumers understand that store brands can provide better value, so they continue to buy store brands rather than manufacturer brands. In short, they show higher loyalty to individual store brands (Richardson et al., 1996).

H3a Consumers' store brand knowledge has a positive effect on individual store brand loyalty.

In terms of store brands' positioning, all retailers stress quality and price. However, quality and price are both compared with the same leading brands or low-priced manufacturer brands, which may result in little quality difference among them. (e. g. , in China market, retailers Carrefour's yellow wine imitates the leading brand He yellow wine, so do Lianhua and Hualian, which results in little quality and few price differences among the store brand yellow wine of these three bit retailers). Consumers' store brand knowledge makes them feel familiar with competitive store brands, and be aware of all store brands' advantages and disadvantages. Therefore, consumers' loyalty to individual store brand may diminish. In addition, from the perspective of store brands' differences among retailers, the same-tier store brands are headed for a similar position, so that there is little or even no difference in perceived quality (Rao, 1969; Richardson, 1997). For example, Richardson et al. (1994) tested five kinds of store brands belonging to two retailers and found that there is no difference in consumers' evaluation on the two retailers' store brands' perceived quality. Consumers' store brand knowledge decreases their preference to one particular store brand. Therefore, it can be expected that store brand knowledge can stimulate consumers' purchase behavior. And due to consumers' understanding of competitive stores, consumers' loyalty to one particular store brand may reduce. Therefore, we assume that:

H3b Consumers' store brand knowledge has a negative effect on individual store brand loyalty. 
Although no consensus has been reached on the characteristics of store brand buyers, researchers in the field tend to believe that store brand buyers are price-sensitive consumers (Hansen et al., 2006). When holding a positive brand attitude, these consumers would be willing to buy store brands, and this willingness is revealed in their sensitivity to price. And due to this, consumers are willing to shift from purchasing the second and third tier manufacturer brands to mid-priced tier or low-priced tier store brands. This attitude makes them willing to switch from manufacturer brands to store brands on all purchasing occasions, thus:

H4a Consumers' store brand attitude has a positive effect on generic store brand loyalty.

Price-sensitive consumers are willing to switch among brands, and their brand inertia and loyalty are low (Corstjens and Lal, 2000). Therefore, consumers with a strong store brand attitude are also less likely to establish higher level of brand loyalty to one particular individual store brand, because their willingness of transforming brands will result in low individual store brand loyalty. In addition, store brand attitude has a positive relationship with consumers' tendency to purchase generic store brands. However, as these consumers demonstrate low individual store brand loyalty, we develop next hypothesis as follows:

H4b Consumers' store brand attitude has a negative effect on individual store brand loyalty.

\subsection{Store Brand Loyalty and Store Loyalty}

With the introduction of store brands, consumers have to decide which one to buy between manufacturer brands and store brands. As above, store brands mainly compete with second and third tier manufacturer brands for most of the customers. For example, Steiner (2004) observed that after retailers introduce store brands, those less competitive manufacturer brands are affected negatively, while the top three manufacturer bands are comparatively less affected. The reason behind this is twofold: one is store brands' poor image compared with national brands (Richardson, 1994), second is some consumers' bias against store brands. Some consumers are always reluctant to buy store brands, no matter how much they can save (Livesey and Lennon, 1978), while other consumers perceive that store brands can provide higher quality value and money-saving value (Sprotta and Shimp, 2004). When consumers transfer from manufacturer brands to store brands, the chance of their purchasing individual store brand will increase. If consumers present higher loyalty to the entire generic store brands, their loyalty to a certain individual store brand of a particular retailer may be higher. 
H5 Generic store brand loyalty has a positive impact on individual store brand loyalty.

The selectivity and quality of the products sold in the stores have important impact on consumers' store selection behavior (Pan and Zinkhan, 2006; Paulins and Geistfeld, 2003). Consumers choose a particular store in order to choose among more products or a special product. Store brands are usually sold exclusively at one store and unavailable at other stores. If consumers are loyal to one store brand, they may become store loyal customers. Cunningham (1961) tested 16 product categories and found that store brand loyalty is positively associated with store loyalty in 13 categories. Corstjens and Lal (2000) demonstrated that store brands can build consumers' store loyalty by increasing their store switch cost.

H6 Individual store brand loyalty has a positive effect on store loyalty.

Fig. 2 shows the relationships among the above hypotheses.

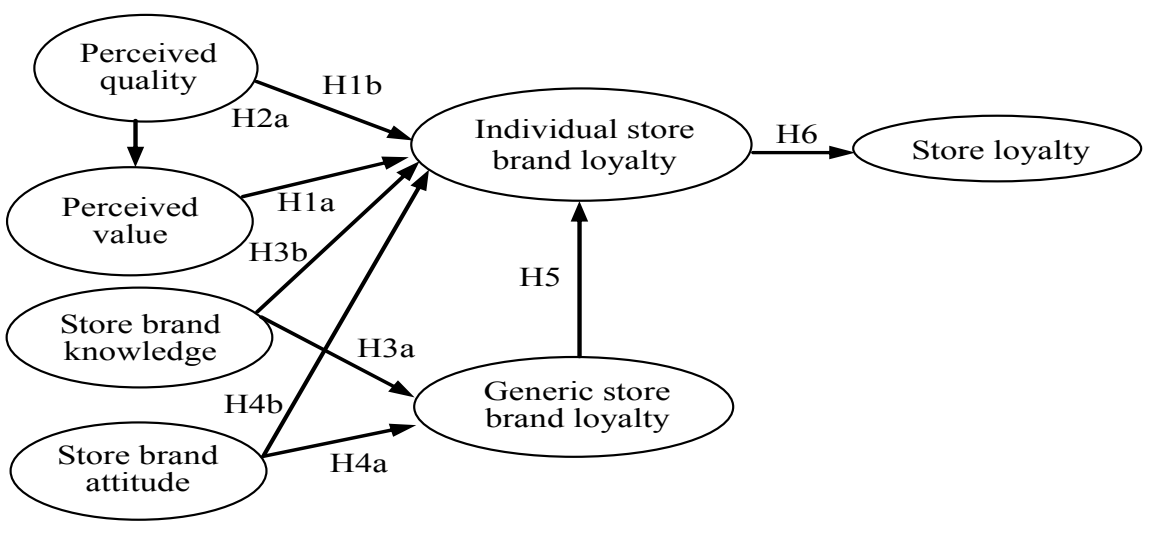

Fig. 2 The Relationships among Hypotheses

\section{Methods}

\subsection{Investigated Store Brands}

Retailer RT-Mart Supermarket has eight stores in Shanghai. RT-Mart Supermarket has launched two tiers of store brands, low-priced tier store brand "Thumb" and mid-priced tier store brand "RT-Mart", both with wide coverage of different products. This study adopted these two tiers of store brands as sample brands because of their wide product coverage and their good market performance. We did not choose other bigger chain retailers such as Lianhua or 
Hualian because the two tiers of store brands strategies are either unimplemented or unclear in these bigger retailers.

To explicitly inform our participants the evaluation subjects are store brands, this article arranged a specific introduction about the concept of store brands, and the distinguishment between generic and individual store brand. Participants were asked whether they have bought the goods of "Thumb" or "RT-Mart" recently. Because RT-Mart Supermarket uses "shaking cards" to mark "store brands" in the shelf position, and store brands have a large range of product coverage, as a result, participants are familiar with store brands in RT-Mart. Due to our explanation and respondents' familiarity with store brands in RT-Mart, we could ensure that respondents were aware that they are commenting on "retailers' store brands".

\subsection{Measurement}

Mature scales were adopted. For measurement of price consciousness, quality consciousness and store loyalty, the study adopted the scale from Ailawadi et al.'s (2001) relevant study. In addition, we used other measurement of store brand knowledge, including the two indices of Dick et al. (1995), and one index of Sethuraman and Cole (1999). For measurement of perceived quality and value, we adopted the scale from Dodds et al.'s study (1991), only deleted the fifth index aimed at durable goods. Furthermore, this research adopted Burton et al.'s 6-indices-scale (1998) to measure store brand attitude, and while in the scale test, we found that the fourth index, "generally speaking, store brands are poor-quality goods", could make consumers confused about the definition, because there are two tiers of store brands, those of poor or high quality, we deleted the index. We also adopted a 4-index scale (Chaudhuri and Holbrook, 2001) to measure brand loyalty (the fourth index was deleted due to its irrelevance), and one index from Richardson et al.'s (1994) study to measure money-saving value. In addition, we compiled one index drawing on Richardson et al.'s study (1994) to measure quality value. All scales adopt the 5-point Likert form, and the coefficients of Cronbach's alpha of all scales in our study are presented in Table 2 .

Table 2 The Sources of Index Scale and the Coefficient of Cronbach's Alpha

\begin{tabular}{llcc}
\hline Measured variable & The source of index scale & $\begin{array}{c}\text { No. of items } \\
\text { Cronbach's } \\
\text { alpha }\end{array}$ \\
\hline Price consciousness & Ailawadi et al. (2001) & 3 & 0.762 \\
Quality consciousness & Ailawadi et al. (2001) & 3 & 0.781 \\
Store loyalty & Ailawadi et al. (2001) & 3 & 0.822 \\
Store brand knowledge & Dick et al. (1995) & 2 & 0.915 \\
\hline & Sethuraman and Cole (1999) & 1 & (To be continued)
\end{tabular}




\begin{tabular}{|c|c|c|c|}
\hline Measured variable & The source of index scale & No. of items & $\begin{array}{l}\text { Cronbach's } \\
\text { alpha }\end{array}$ \\
\hline Perceived value & Dodds et al. (1991) & 5 & 0.814 \\
\hline Perceived quality (delete the fifth index) & Dodds et al. (1991) & 4 & 0.925 \\
\hline $\begin{array}{l}\text { Store brand attitude } \\
\text { (delete the fourth index) }\end{array}$ & Burton et al. (1998) & 5 & 0.797 \\
\hline Brand loyalty (delete the fourth index) & Chaudhuri and Holbrook (2001) & 3 & 0.918 \\
\hline Money-saving value & Richardson et al. (1994) & 1 & \\
\hline Quality value & The current study & 1 & \\
\hline
\end{tabular}

\subsection{Procedure and Sample}

This study randomly selected participants at different supermarket gates (e.g., Lianhua, Hualian, RT-Mart, Carrefour, Lotus, etc.) in Shanghai, China. The majority of these respondents have bought the store brands in RT-Mart. Participants could receive a small gift worth 2 RMB yuan for completing one questionnaire. 400 questionnaires were distributed, and a total of 338 valid questionnaires were returned. Table 3 presents the sample profile.

Table 3 Sample Profile

\begin{tabular}{llr||llr}
\hline Variables & Attributes & Percentage & Variables & Attributes & Percentage \\
\hline Gender & Male & $38.4 \%$ & Income per month & No income & $8.1 \%$ \\
& Female & $61.6 \%$ & (yuan) & $1-700$ & $1.7 \%$ \\
Education & Elementary school & $3.8 \%$ & & $701-1000$ & $17.9 \%$ \\
& Junior high & $35.3 \%$ & & $1001-1600$ & $27.2 \%$ \\
& $\quad$ school & & & & \\
& Polytechnic or senior & $37.0 \%$ & & $1601-2000$ & $17.9 \%$ \\
& $\quad$ high school & & & & \\
& Junior college & $17.3 \%$ & & $2001-3000$ & $12.4 \%$ \\
& Undergraduate college & $5.8 \%$ & & $3001-5000$ & $10.2 \%$ \\
Age & Graduated college & $0.8 \%$ & & $>5001$ & $4.6 \%$ \\
& <20 & $2.6 \%$ & Age & $40-49$ & $23.4 \%$ \\
& $20-24$ & $11.6 \%$ & & $50-59$ & $8.4 \%$ \\
& $25-29$ & $22.8 \%$ & & $>=60$ & $0.6 \%$ \\
& $30-39$ & $30.6 \%$ & & & \\
\hline
\end{tabular}

\subsection{Definition of 2-tier Store Brands' Target Customers}

Corstjens and Lal (2002) proposed that in fast-moving consumption goods, customers can be divided into two segment markets according to their balance of choice in price and quality, i.e., quality-sensitive and price-sensitive customers. They also suggested that in some product categories, some consumers are 
balancers between quality and price, and their choice may not be obvious, so that they can be classified as medial segment market between quality-sensitive and price-sensitive consumers. But generally, a majority of consumers can be divided into two quality-sensitive or price-sensitive segment markets. This study accepted Corstjens and Lal's (2002) viewpoint, and classified store brands' purchasers into two segment markets. The consumer's sensitive to price may be real or potential buyers of low-priced tier store brands, while those sensitive to quality may be the real or potential buyers of mid-priced tier store brands. And because some consumers are between these two segment markets, their evaluation for these two tiers will be used in the corresponding tier regression analysis.

After calculating the mean of 3 indices of price consciousness, we regarded those whose price consciousness is higher than 3.00 as consumers belonging to low-priced tier segment market. And then we adopted their evaluation results of "Thumb", but did not use their evaluation of "RT-Mart". Similarly, we regarded those whose quality consciousness is higher than 3.00 as consumers belonging to mid-priced tier segment market. Then, we adopted their evaluation results of "RT-Mart", but did not use their evaluation of "Thumb". There were 280 questionnaires which indicate that participants' price consciousness is higher than 3.00 , representing $81 \%$ of the total samples, and these questionnaires belong to "Thumb". What's more, there were 268 questionnaires which indicate that participants' quality consciousness is higher than 3.00, representing $77 \%$ of the total questionnaires, and these questionnaires belong to "RT-Mart". Hence, we saw that there are a large part of consumers rocked in price-sensitive and quality-sensitive segment.

\section{Results}

We employed LISREL 8.7 to analyze the two tiers of store brands separately. In the low-priced tier, $X^{2}=863.95, d . f .=287$, RMSEA $=0.085$, NFI $=0.96$, CFI $=0.96$, IFI $=0.96, \mathrm{GFI}=0.81 . X^{2} / d . f$. is 3.01 , and close to 2 ; although RMSEA is no less than 0.08 , its value is acceptable. NFI, NNFI, CFI, and IFI are all higher than 0.95 , and only GFI is a bit low. However, as a whole, low-priced tier model and data fit very well. In the mid-priced tier, $X^{2}=704.11, d . f=287$, RMSEA $=0.074$, $\mathrm{NFI}=0.95, \mathrm{NNFI}=0.97, \mathrm{CFI}=0.97, \mathrm{IFI}=0.97, \mathrm{GFI}=0.83 . X^{2} / d . f$. is 2.45 , and close to 2; RMSEA is less than 0.08; NFI, NNFI, IFI, and CFI are all higher than 0.95 . Although the value of GFI is a bit lower, the fitting between mid-priced tier model and data is satisfactory as a whole.

As we can see from Table 4, both in the low-priced and mid-priced tier, store brand knowledge has no effect on generic and individual store brand loyalty, and 
store brand attitude has no impact on individual store brand loyalty, either. All other variables have significant effect. Therefore, except H3a, H3b, H4b, other hypotheses in the Table 4 are supported. Because perceived quality has a positive correlation with perceived value and individual store brand loyalty; perceived value is positively associated with individual store brand loyalty; and individual store brand loyalty also has positive effect on store loyalty, perceived value has positive impact on store loyalty. H1c is supported.

Table 4 Model Fitting Indices and Hypotheses Test

\begin{tabular}{|c|c|c|c|c|c|c|}
\hline \multirow[t]{2}{*}{ Hypothesis } & \multicolumn{2}{|c|}{$T$ value } & \multicolumn{2}{|c|}{$\begin{array}{c}\text { Standardized path } \\
\text { coefficient }\end{array}$} & \multicolumn{2}{|c|}{ Results } \\
\hline & $\begin{array}{l}\text { Low-pricec } \\
\text { tier }\end{array}$ & $\begin{array}{l}\text { Mid-priced } \\
\text { tier }\end{array}$ & $\begin{array}{l}\text { Low-priced } \\
\text { tier }\end{array}$ & $\begin{array}{l}\text { Mid-priced } \\
\text { tier }\end{array}$ & $\begin{array}{l}\text { Low-priced } \\
\text { tier }\end{array}$ & $\begin{array}{l}\text { Mid-priced } \\
\text { tier }\end{array}$ \\
\hline $\begin{array}{l}\text { H1a (perceived quality } \rightarrow \\
\text { perceived value) }\end{array}$ & 6.51 & 6.26 & 0.56 & 0.49 & Supported & Supported \\
\hline $\begin{array}{l}\mathrm{H} 1 \mathrm{~b} \text { (perceived quality } \rightarrow \\
\text { individual store brand loyalty) }\end{array}$ & 3.97 & 3.02 & 0.27 & 0.21 & Supported & Supported \\
\hline $\begin{array}{l}\mathrm{H} 2 \mathrm{a} \text { (perceived value } \rightarrow \\
\quad \text { individual store brand loyalty) }\end{array}$ & 4.85 & 6.23 & 0.32 & 0.44 & Supported & Supported \\
\hline $\begin{array}{l}\text { H3a (store brand knowledge } \rightarrow \\
\text { generic store brand loyalty) }\end{array}$ & 0.80 & -0.37 & 0.09 & -0.05 & $\begin{array}{l}\text { Not } \\
\text { supported }\end{array}$ & $\begin{array}{l}\text { Not } \\
\text { supported }\end{array}$ \\
\hline $\begin{array}{l}\mathrm{H} 3 \mathrm{~b} \text { (store brand knowledge } \rightarrow \\
\text { individual store brand loyalty) }\end{array}$ & -0.14 & -0.68 & -0.02 & -0.10 & $\begin{array}{l}\text { Not } \\
\text { supported }\end{array}$ & $\begin{array}{l}\text { Not } \\
\quad \text { supported }\end{array}$ \\
\hline $\begin{array}{l}\text { H4a (store brand attitude } \rightarrow \\
\text { generic store brand loyalty) }\end{array}$ & 7.06 & 6.46 & 0.82 & 0.95 & Supported & Supported \\
\hline $\begin{array}{l}\mathrm{H} 4 \mathrm{~b} \text { (store brand } \\
\text { attitude } \rightarrow \text { individual store } \\
\text { brand loyalty) }\end{array}$ & 0.17 & 0.44 & 0.03 & 0.11 & $\begin{array}{l}\text { Not } \\
\text { supported }\end{array}$ & $\begin{array}{l}\text { Not } \\
\text { supported }\end{array}$ \\
\hline $\begin{array}{l}\text { H5 (generic store brand } \\
\text { loyalty } \rightarrow \text { individual store } \\
\text { brand loyalty) }\end{array}$ & 2.63 & 2.22 & 0.38 & 0.36 & Supported & Supported \\
\hline $\begin{array}{c}\text { H6 (individual store brand } \\
\text { loyalty } \rightarrow \text { store loyalty) }\end{array}$ & 4.10 & 3.42 & 0.27 & 0.24 & Supported & Supported \\
\hline
\end{tabular}

In addition, in order to test whether generic store brand loyalty has a direct effect on store loyalty, we extended the model above into a competition model. Based on the above model, we added an additional hypothesis assuming that generic store brand loyalty has direct effect on store loyalty. Low-priced tier model $\left(X^{2}=858.29, d . f .=286, \mathrm{RMSEA}=0.085, \mathrm{NFI}=0.95, \mathrm{NNFI}=0.96, \mathrm{CFI}=0.97\right.$, $\mathrm{IFI}=0.97, \mathrm{GFI}=0.81)$ and mid-priced tier model $\left(X^{2}=696.22\right.$, d.f. $=286$, RMSEA $=0.073, \mathrm{NFI}=0.95, \mathrm{NNFI}=0.97, \mathrm{CFI}=0.97, \mathrm{IFI}=0.97, \mathrm{GFI}=0.83$ ) both have good fitting indices. In the low-priced tier, the path coefficient's T value of individual store brand loyalty on store loyalty is $0.42 \quad(p>0.05)$, and its standardized path coefficient is 0.12 ; and in the mid-priced tier, its path 
coefficient's T value is $0.52(p>0.05)$ and its standardized path coefficient is 0.14 . Their path coefficients are both insignificant. Thus, generic store brand loyalty has no direct effect on store loyalty.

This study simply classified store brands' perceived value of consumers into two dimensions (Richardson et al., 1994). We regarded perceived value as dependent variable, and money-saving value and quality value as independent variables to carry out regression analysis, and got regression equation of the two tiers. Table 5 presents the specific indices. The tolerance of two tiers of store brands is close to 1; VIF is near 1 and less than 10 , so these independent variables are non-collinear; and their $\mathrm{T}$ value are both bigger than 2 , which indicates they have significant effect. From the regression result, whether in low-priced tier or mid-priced tier, the value of money-saving value's regression coefficient is both larger than that of quality value. Thus, consumers all pay more attention to money-saving value, rather than its quality value. Hence, H2b is not supported.

Table 5 Regression Analysis of Perceived Value (Dependent Variable: Perceived Value)

\begin{tabular}{|c|c|c|c|c|c|c|c|}
\hline \multicolumn{2}{|l|}{ Tier } & \multirow{3}{*}{$\begin{array}{c}\begin{array}{c}\text { Unstandardized } \\
\text { coefficient }\end{array} \\
1.838 \\
0.306\end{array}$} & \multirow[t]{2}{*}{$\begin{array}{c}\text { Standardized } \\
\text { coefficient }\end{array}$} & \multirow{2}{*}{$\begin{array}{c}T \text { value } \\
13.666\end{array}$} & \multirow{2}{*}{ Tolerance } & \multirow{2}{*}{ VIF } & \multirow{2}{*}{$\begin{array}{c}R^{2} \\
0.300\end{array}$} \\
\hline Low-priced & Constant & & & & & & \\
\hline tier & $\begin{array}{l}\text { Money-saving } \\
\text { value }\end{array}$ & & 0.420 & 8.065 & 0.932 & 1.073 & \\
\hline & Quality value & 0.214 & 0.258 & 4.961 & 0.932 & 1.073 & \\
\hline \multirow{3}{*}{$\begin{array}{l}\text { Mid-priced } \\
\text { tier }\end{array}$} & Constant & 1.852 & & 14.693 & & & \multirow{3}{*}{0.362} \\
\hline & $\begin{array}{l}\text { Money-saving } \\
\text { value }\end{array}$ & 0.386 & 0.537 & 10.169 & 0.865 & 1.156 & \\
\hline & Quality value & 0.112 & 0.138 & 2.620 & 0.865 & 1.156 & \\
\hline
\end{tabular}

As we can see from the above hypothesis tests, store brands' perceived quality and perceived value of low-priced tier are both positively related to their individual store brand loyalty. Furthermore, individual store brand loyalty has positive effect on store loyalty. Similarly, store brands' perceived quality and perceived value of mid-priced tier are positively related to their individual store brand loyalty, and their individual store brand loyalty have positive effect on store loyalty. Therefore, both of these two kinds of store brands have a positive impact on building store loyalty, and $\mathrm{H} 7$ is not supported.

\section{Discussion and Conclusion}

From the above results, we can see that store brands' perceived quality can play an important role in consumers' purchase. And it can directly affect perceived 
value, and also has some direct and indirect effect on store brand loyalty. This article empirically validates the opinion held by scholars arguing that the key factor in determining the purchase of store brands is perceived quality (Richardson et al., 1994). Just because store brands' perceived quality of Chinese local retailers is poor, it cannot provide corresponding quality benefits to consumers, which leads to Chinese local retailers store brands' poor market performance (Jiang and Guo, 2003; Wang, 2006).

This article argues that store brand loyalty is significantly affected by store brands' perceived value. Studying under the American market text, Richardson et al. (1994) found that consumers give more attention to store brands' quality value, rather than their money-saving value. However, this paper finds that consumers pay more attention to money-saving value both in low-priced tier and mid-priced tier, which is consistent with Szybillo and Jacoby's (1974) conclusion that "money-saving value has more positive effect on purchase intention than quality value", and is nevertheless contrary to the characteristic that store brands' consumers in America preferred quality value (Richardson et al., 1994).

Scholars find that consumers' familiarity with store brands can heighten their purchase intention (Richardson et al., 1996). Consequently, in order to improve consumers' purchase, retailers always increase consumers' store brand knowledge (Wang and Yang, 2007). In contrast, however, this paper argues that consumers' store brand knowledge does not have durable effect on their purchase behavior. And the knowledge neither influence consumers' store brand loyalty, nor does it have any impact on individual store brand loyalty or generic store brand loyalty.

Store brand attitude reflects consumers' acceptance of store brands. Burton et al. (1998) stated that store brand attitude strongly affects the purchase of store brands, but this paper proves that store brand attitude of consumers just has significant effect on generic store brand loyalty, but not on individual store brand loyalty. Accordingly, relative to the attitude of manufacturer brands, store brand attitude only indicates that consumers are willing to accept products provided by retailers and purchase store brands of all retailers. However, whether consumers are loyal to one particular individual store brand owned by one certain retailer, and then loyal to the store, is dependent on whether the individual store brand can offer higher value to consumers. That is because retailers' store brands not only have to compete with manufacturer brands, but also with individual store brands provided by other retailers. If retailers want consumers to prefer a particular store brand, the store brand has to possess some special characteristics and higher attraction.

Scholars argue that the success of retailers' store brands is positively related to store brands of other retailers (Rao, 1969), namely, "spillover effect". Similarly, 
this article states that generic store brand loyalty has positive effect on individual store brand loyalty, that is to say, if consumers are loyal to the entire generic store brands instead of manufacturer brands, then there is a prerequisite that they are loyal to a particular individual store brand of one certain retailer. As this article demonstrates that there exists individual store brand loyalty, and individual store brand can build a certain degree of differentiation among retailers, which is inconsistent with the opinion supported by Rao (1969) and Richardson (1997) that "store brand could not create differentiation among retailers, and it is an another kind of brand relative to manufacturer brand".

When consumers have preference and loyalty to a particular individual store brand, they will choose the store from which they purchase this store brand. Consequently, store brand loyalty results in consumers' store loyalty. Some researchers argue that low-priced tier store brands cannot develop store loyalty (Corstjens and Lal, 2000), but conversely, in this study, we find that both low-priced tier and mid-priced tier store brands can build store brand loyalty, and then both result in consumers' store loyalty. This finding has important managerial implications for Chinese local retailers. By providing 2-tier or 3-tier store brands, Chinese local retailers can meet the needs of different segment markets and create store loyalty in different segment markets.

This article has three contributions to "store brand research". First, we define two store brand concepts, which provide a new perspective for the exploration of the relationship between store brand and store loyalty. Then we divide store brands into generic and individual store brands, and furthermore we classify store brand loyalty into generic and individual store brand loyalty. Through this, we can more specifically examine the relationship between store brands and store loyalty. The second contribution is the design of research. We only adopt the evaluation data of target respondents in the analysis of the two tiers, which is distinguished from the past survey studies of store brands. Thirdly, in Chinese market text, we find that store brand knowledge has no effect on store brand loyalty or store loyalty; and consumers care more about money-saving value of store brands. In addition, both low-priced tier and mid-priced tier store brands can develop store loyalty.

The limitations of the study are as follows. First, as the sample of our study is confined in Shanghai, China, the lack of typicality might influence the applicability of our conclusions. Second, this paper only investigates the two tiers of store brands in RT-Mart, which only has eights stores in Shanghai and some participants of our study might be not very familiar with this brand. Third, we don't specify one or several products when doing surveys, and generally define them as two tiers of store brands. However, there may be some difference in terms of the quality and pricing of the same tier store brands, which will bring 
uncertainty to consumers' quality assessment, value assessment and other behavioral intention assessment. As a result, the assessment result may be affected. Hence, the research result of this paper should be further tested.

\section{Managerial Implications}

The findings in this study have, as we believe, some valuable managerial implications for Chinese local retailers to improve their competitive advantage, develop and manage store brands. As a whole, this article has four implications as follows.

\subsection{Building Store Differentiation and Store Loyalty through Store Brands}

Store brands can be completely controlled and exclusively distributed by retailers, and have high profit margins. In addition, store brands can be regarded as a substitute for manufacturer brands, and can also create consumers' store brand loyalty (Wang and Yang, 2007). This article suggests that both mid-priced tier and low-priced store brands can build store brand loyalty and store loyalty. Retailers can be easily imitated by their competitors in distributing manufacturer brands and adopting other marketing service strategies. However, their store brands cannot be easily imitated. And retailers can build store differentiation and consumers' store loyalty through one or several store brands owned by them. Thus, Chinese local retailers should rapidly develop store brands in order to build store differentiation and store loyalty.

\subsection{Developing Multi-tier Store Brands}

Retailers can attract and retain consumers in different segment markets to shop in their stores by 2-tier or 3-tier store brands with different positioning. UK retailers generally adopt 3-tier store brands, and German retailers mainly sell store brands in discount stores; while in the market of United States, Belgium, France, and Spain, store brands are between these two kinds of states (Lamey et al., 2007). For example, among store brand in Wal-Mart, "Great value" is low-quality brand, while "Sam's American Choice" is high-quality brand. For apple juice, "Great value" offers condensed apple juice; "Sam's American Choice" offers high-quality and fresh squeezed apple juice (Yang and Wang, 2007). In Chinese market, RT-Mart implements 2-tier store brands strategy. In addition, a majority of local retailers mainly adopt single tier store brand. In other cases, their tiers strategies are ambiguous. In order to meet the demand of a number of segment 
markets and cultivate consumers' store loyalty, local retailers need to develop multi-tier store brands.

The paper shows that in order to more clearly express store brands' perceived quality to consumers, retailers need to position their store brands preciously, and let consumers know which brands belong to low-priced or mid-priced tier. That is because the product coverage of store brands is pretty wide. If store brands can not maintain its positioning consistently, consumers will have a corresponding ambiguous perception. For example, some Chinese local retailers do not have an explicit positioning for store brands: in some product categories, their store brands are mid-priced; but in other product categories, their store brands bearing the same brand name become the-lowest-price products. This reflects that local retailers have an inaccurate store brand positioning, and they are in a lack of confidence about their store brands. Obviously, these marketing strategies can not increase consumers' purchase confidence, which may be one of the main reasons behind local store brands' poor performance (Wang, 2006). Therefore, in order to meet multi-level demand, retailers need to introduce multi-tier store brands (Wang and Yang, 2007). Besides, in order to show the quality of the store brands and their target groups, after positioning of the brand, retailers should persist on the original brand positioning consistently in all product categories where the store brand penetrate, even in high-risk product categories.

In order to prevent the negative effect of low-priced tier store brands on mid-priced tier and high-premium tier store brands and retailers' store image, retailers should keep low-priced tier store brands' name distant. It is not only from the mid priced tier and high-premium tier store brands, but also from retailers' store name. One of the tactics retailers can adopt is that they can name the low-priced tier store brands by concealing the store name. To illustrate, retailer RT-Mart' low-priced tier store brand "thumb" conceals RT-Mart's name, and consumers cannot see the name of "RT-Mart" on the package of "thumb" products, which avoids the negative impact of low quality on store brands. Conversely, store brand "RT-Mart" positioned on mid-priced tier adopts its store name.

\subsection{Intensifying Store Brands' Perceived Quality}

As store brands have a wide range of product coverage, the investment in brand image cannot match with that of in manufacturer brands. In addition, store brands cannot offer high emotional or symbolic value to consumers, and as a result, store brands have to offer high quality value to attract consumers. One of the most important factors influencing the purchase of store brands is their perceived quality (Dhar and Hah, 1997). This paper points out that store brands' perceived 
quality has important effect on perceived value, store brand loyalty, and store loyalty. Furthermore, retailers should enhance store brands' perceived quality, rather than position it as a higher quality product. For example, for the low-priced tier store brands, retailers should make consumers clear that store brands' quality is acceptable, and then attract them to purchase for "the lowest price". Similarly, for mid-price tier store brands, retailers also should let consumers know that the quality of store brands is equal with the leading brands in manufacturer brands, and then attract them to purchase for "relatively lower price".

\subsection{Actively Communicating Store Brands' Perceived Value}

Retailers also need to actively communicate store brands' perceived value to consumers when they attempt to enhance store brands' perceived quality. Compared with manufacturer brands, the large part of value offered by store brands is money-saving value and quality value. However, from the findings of this study, consumers pay more attention to money-saving value of store brands, so the money-saving value of store brand products should be more saliently emphasized. In addition, retailers also need to convey the notion that their store brands have higher value relative to other retailers' store brands. This is because in terms of consumers' store selection, consumers do not care about the value of store brands compared with that of manufacturer brands, but with that of other retailers' store brands. As a result, only when the value of one retailer's store brand is higher than that of other retailers' can consumers' store loyalty be established.

\subsection{Strengthening Features of Store Brands}

Retailers should strengthen the unique characteristics of their individual store brands. Only distinctive individual store brands can induce higher individual store brand loyalty as well as higher store loyalty. One of the reasons why store brands of Chinese local retailers have poor performance is that they are in lack of features compared with store brands of other retailers. As a result, consumers are reluctant to have high loyalty toward one particular individual store brand. Store brands have to compete not only with manufacturer brands in the stores, but also with store brands of other retailers. If consumers can not identify the difference among individual store brands, they will buy retailer' store brands in any stores, and they would just switch from manufacturer brands to any store brands, rather than a specific store brand. Nevertheless, consumers will not generate the store brand preference and the interest toward one particular individual store brand. Therefore, consumers cannot develop individual store 
brand loyalty and the corresponding store loyalty. Only distinctive individual store brands can develop consumers' individual store brand loyalty, and then build store loyalty.

Acknowledgements This work is supported by the Humanities and Social Science Program "Graduate Student Innovation Fund" of the Ministry of Education (No. 07JA630040), and the third phase of " 211 University Program" in Shanghai University of Finance \& Economics. The authors gratefully acknowledge the valuable suggestions proposed by experts and scholars at the Doctoral Consortium of 2007 JMS (Journal of Marketing Science) Annual Conference and Doctoral Consortium of Chinese Marketing and the useful revisions raised by two anonymous reviewers. The authors in particular thank Wei Song, Daojun Wang, Fan Zhang and Zhiqin Zou for their help and assistance in developing this paper.

\section{References}

Ailawadi K L, Neslin S A, Gedenk K (2001). Pursuing the value-conscious consumer: Store brands versus national brand promotions. Journal of Marketing, 65(1): 71-89

Ailawadi, K L, Pauwels K, Steenkamp J-B E M (2008). Private-label use and store loyalty. Journal of Marketing, 72(4): 19-30

Bell D R, Ho T-H, Tang C S (1998). Determining where to shop: Fixed and variable cost of shopping. Journal of Marketing Research, 35(3): 352-369

Bloemer J, Ruyter K D (1998). On the relationship between store image, store satisfaction and store loyalty. European Journal of Marketing, 32(5): 499-513

Bridson K, Evans J (2004). The secret to a fashion advantage is brand orientation. International Journal of Retail \& Distribution Management, 32(8/9): 403-411

Burton S, Lichtenstein D R, Netemeyer R G, Garretson J A (1998). A scale for measuring attitude toward private label products and an examination of its psychological and behavioral correlates. Journal of the Academy of Marketing Science, 26(4): 293-306

Chaudhuri A, Holbrook M B (2001). The chain of effects from brand trust and brand affect to brand performance: The role of brand loyalty. Journal of Marketing, 65(2): 81-93

Chen S-C, Quester P G (2006). Modeling store loyalty: Perceived value in market orientation practice. Journal of Services Marketing, 20(3): 188-198

Corsthens M, Lal R (2000). Building store loyalty through store brands. Journal of Marketing Research, 37(3): 281-291

Cunningham R M (1961). Customer loyalty to store and brand. Harvard Business Review, 39: 127-137

Darley W K, Lim J-S (1993). Store-choice behavior for pre-owned merchandise. Journal of Business Research, 27(1): 17-31

Dhar S K, Hoch S J (1997). Why store brand penetration varies by retailer. Marketing Science, 16(3): 208-227

Dick A, Jain A, Richardson P (1995). Correlates of store brand proneness: Some empirical observations. Journal of Product \& Brand Management, 4(4): 15-22

Dodds W B, Monroe K B, Grewal D (1991). Effects of price, brand, and store information on buyers' product evaluations. Journal of Marketing Research, 28(3): 307-319

Hansen K, Singh V, Chintagunta P (2006). Understanding store-brand purchase behavior 
across categories. Marketing Science, 25(1): 75-90

Harcar T, Kara A, Kucukemiroglu O (2006). Consumer's perceived value and buying behavior of store brands: An empirical investigation. The Business Review, 5(2): 55-62

Johanson U, Burt S (2004). The buying of private brands and manufacturer brands in grocery retailing: A comparative study of buying processes in the UK, Sweden and Italy. Journal of Marketing Management, 20(7-8): 799-824

Kirmant A, Baumgartner H (2000). Reference points used in quality and value judgments. Marketing Letters, 11(4): 299-310

Koo D-M (2003). Inter-relationships among store images, store satisfaction, and store loyalty among Korea discount retail patrons. Asia Pacific Journal of Marketing and Logistics, 15(4): $42-71$

Lamey L, Deleersnyder B, Dekimpe M G, Steenkamp J-B E M (2007). How business cycles contribute to private-label success: Evidence from the United States and Europe. Journal of Marketing, 71(1): 1-15

Livesey F, Lennon P (1978). Factors affecting consumers' choice between manufacturer brands and retailer own labels. European Journal of Marketing, 12(2): 158-170

Mieres C G, Martin A M D, Getierrez J A T (2006). Antecedents of the difference in perceived risk between store brands and national brands. European Journal of Marketing, 40(1/2): 61-82

Miquel S, Caplliure E M, Aldas-Manzano J (2002). The effect of personal involvement on the decision to buy store brands. The Journal of Product and Brand Management, 11(1): 6-18

Miranda M J, Konya L, Havrila I (2005). Shoppers' satisfaction levels are not the only key to store loyalty. Marketing Intelligence \& Planning, 23(2): 220-232

Pan Y, Zinkhan G M (2006). Determinants of retail patronage: A meta-analytical perspective. Journal of Retailing, 82(3): 229-243

Parasurman A, Grewal D (2000). The impact of technology on the quality-value-loyalty chain: A research agenda. Journal of the Academy of Marketing Science, 28(1): 168-174

Paulins V A, Geistfeld L V (2003). The effect of consumer perceptions of store attributes on apparel store preference. Journal of Fashion Marketing and Management, 7(4): 371-385

Pauwels K, Srinivasan S (2004). Who benefits from store brand entry? Marketing Science, 23(3): 364-390

Quelch J, Harding D (1996). Brands versus private labels: Fighting to win. Harvard Business Review, 74(1): 99-111

Rafio M, Fulford H (2005). Loyalty transfer from offline to online stores in the UK grocery industry. International Journal of Retail \& Distribution Management, 33(6): 444-460

Rao T R (1969). Are some consumers more prone to purchase private brands? Journal of Marketing Research, 6(4): 447-450

Reinartz W J, Kumar V (1999). Store-, market-, and consumer-characteristics: The drivers of store performance. Marketing Letters, 10(1): 5-22

Reynolds K E, Arnold M J (2000). Customer loyalty to the salesperson and the store: Examining relationship customers in an upscale retail context. The Journal of personal Selling \& Sales Management, 20(2): 89-98

Richardson P S (1997). Are store brands perceived to be just another brand? Journal of Product \& Brand Management, 6(6): 388-404

Richardson P S, Dick A S, Jain A K (1994). Extrinsic and intrinsic cue effects on perceptions of store brand quality. Journal of Marketing, 58(4): 28-36

Richardson P S, Jain A K, Dick A S (1996). Household store brand proneness: A framework. Journal of Retailing, 72(2): 159-185 
Rintamaki T, Kanto A, Kuusela H, Spence M T (2006). Decomposing the value of department store shopping into utilitarian, hedonic and social dimensions: Evidence from Finland. International Journal of Retail \& Distribution Management, 34(1): 6-24

Sayman S, Hoch S J, Raju J S (2002). Positioning of store brands. Marketing Science, 21(4): 378-397

Sethuraman R, Cole C (1999). Factors influencing the price premiums that consumers pay for national brands over store brands. Journal of Product \& Brand Management, 8(4): 340-351

Sirgy M S, Samli A C (1985). A path analytic model of store loyalty involving self-concept, store image, geographic loyalty, and socioeconomic status. Journal of Academy of Marketing Science, 13(3): 265-291

Sivakumar K, Rai S P (1997). Quality tier competition: How price change influences brand choice and category choice. Journal of Marketing, 61(3): 71-84

Smith J B, Colgate M (2007). Customer value creation: A practical framework. Journal of Marketing Theory and Practice, 15(1): 7-23

Sprotta D E, Shimp T A (2004). Using products sampling to augment the perceived quality of store brands. Journal of Retailing, 80(4): 305-315

Steiner R L (2004). The nature and benefits of national brand/private label competition. Review of Industrial Organization, 24(2): 105-127

Szybillo G J, Jacoby J (1974). Intrinsic versus extrinsic cues as determinants of perceived product quality. Journal of Applied Psychology, 59(February): 74-78

Yang Z L, Peterson R T (2004). Customer perceived value, satisfaction, and loyalty: The role of switching costs. Psychology \& Marketing, 21(10): 799-818

白长虹, 刘炽 (Bai Changhong, Liu Chi) (2002). 服务企业的顾客忠诚及其决定因素研究 (Customer loyalty and its determinants for service firms). 南开管理评论, 5(6): 64-69

符国群 (Fu Guoqun) (2001). 西方零售商品牌给制造商带来的机会和挑战 (Opportunity and challenge brought by the producer of the western retail brands). 南开管理评论, 4(2): 48-50

黄劲松, 赵平, 王高, 陆奇斌 (Huang Jinsong, Zhao Ping, Wang Gao, Lu Qibin) (2004). 基于顾 客角度的市场占有率研究 (Market share research based on customer orientation). 中国管理 科学, (2): 95-101

江明华, 郭否 (Jiang Minghua, Guo Lei) (2003). 商店形象与自有品牌感知质量的实证研究 (An empirical study of store image and private brand's perceived quality). 经济科学, (4): $119-128$

李飞, 程丹 (Li Fei, Cheng Dan) (2006). 西方零售商自有品牌理论研究综述 (A summary of research on retailers' private brand theory in the west). 北京工商大学学报 (社会科学版), (1): $1-5$

陆娟 (Lu Juan) (2005). 服务忠诚驱动因素与驱动机理：基于国内外相关理论和实证研究的系统 分析 (Driving factors and mechanism of service loyalty: An systemic analysis based on theories and empirical studies at home and abroad). 管理世界, (6): 107-125

汪旭晖 (Wang Xuhui) (2006). 中国零售商自有品牌实施的难点及对策 (Difficulties confronting the development of Chinese retailers' private brand and the countermeasures). 经济与管理, 20(5): 59-62

汪纯孝, 韩小芸, 温碧燕 (Wang Chunxiao, Han Xiaoyun, Wen Biyan) (2003). 顾客满意感与忠 诚感关系的实证研究 (An empirical study of the relationship between customer satisfaction and loyalty). 南开管理评论, (4): 70-74

王新新, 杨德锋 (Wang Xinxin, Yang Defeng) (2007). 自有品牌与零售商竞争力研究 (Study on the private brand and the sustained competitive advantage of the retail company). 哈尔滨商 业大学学报 (社科版), (6): 94-97

许云莲, 蒋青云 (Xu Yunlian, Jiang Qingyun) (2007). 消费者对大卖场自有品牌的偏好及其影响 
因素: 基于上海市场的实证研究 (Consumers preferences to private brand of supermarket and influencing factors: An empirical research in Shanghai). 市场营销导刊, (1): 14-17

杨德锋, 王新新 (Yang Defeng, Wang Xinxin) (2007). 零售商自有品牌感知质量的形成与提升研 究 (The forming and increasing of the retail store brands perceived quality: Based on the cues). 消费经济, (6): 68-71 